\title{
VIP-PACAP 2010: My Own Perspective on Modulation of Cognitive and Emotional Behavior
}

\author{
Illana Gozes
}

Published online: 5 October 2010

(C) Springer Science+Business Media, LLC 2010

Editorial: From the Desk of the Editor-in-Chief

This editorial focuses on cognitive and emotional behavior in relation to vasoactive intestinal peptide (VIP; Said and Mutt 1972), pituitary adenylate cyclase activating polypeptide (PACAP; Arimura 1992), and our original discovery of the VIP-regulated activity-dependent neuroprotective protein (ADNP) and its peptide derivative, drug candidate NAP (NAPVISPQ, generic name davunetide; Bassan et al. 1999; Gozes et al. 2009).

About 20 years ago we showed that in vivo inhibition of VIP by a hybrid peptide antagonist resulted in reduced sexual/ social interactions (Gozes et al. 1989) and impairment of diurnal rhythms (Gozes et al. 1995). The hybrid VIP antagonist potently inhibited VIP-associated cyclic adenosine monophasphatase (cAMP) formation and VIP-related neuroprotection in cell cultures (Gozes et al. 1991). Following intracerebral administration in rats, this VIP antagonist and the external envelope glycoprotein (gp120) of the human immunodeficiency virus produced similar retardation of spatial discrimination (Glowa et al. 1992), suggesting that both impair memory for spatially related stimulus control. We have further shown that this impairment was ameliorated by VIP treatment, implicating VIP as a protective factor against dementia related to the acquired immunodeficiency syndrome (Glowa et al. 1992). We next showed that modulating VIP gene activity by genetic manipulations resulting in reduced peptide expression, leads to spatial memory impairment in mice (Gozes et al. 1993). Conversely,

\section{Gozes $(\bowtie)$}

The Lily and Avraham Gildor Chair for the Investigation of Growth Factors and The Adams Super Center for Brain Studies Sackler Faculty of Medicine,

Tel Aviv University,

Tel Aviv 69978, Israel

e-mail: igozes@post.tau.ac.il in a rat model of Alzheimer's disease, we demonstrated that intranasal administration of VIP analogues improved cognitive behavior and protected against cholinotoxicity (Gozes et al. 1996; Gozes et al. 1999).

Our more recent studies followed the VIP-regulated ADNP and its peptide derivative NAP (NAPVISPQ; Bassan et al. 1999) and showed that ADNP knockout was embryonic lethal at the time of brain formation (Mandel et al. 2007; Pinhasov et al. 2003). We then demonstrated that partial ADNP deficiency $(\mathrm{ADNP}+/-)$ resulted in cognitive and social impairments that were coupled to tauopathy, a major pathology in Alzheimer's disease and frontotemporal dementia (Vulih-Shultzman et al. 2007). In the ADNP-deficient model (Vulih-Shultzman et al. 2007) as well as in models of Alzheimer's disease (Matsuoka et al. 2007; Matsuoka et al. 2008) and frontotemporal dementia (Shiryaev et al. 2009), we showed that intranasal administration of NAP ameliorated spatial memory impairments and inhibited tau-related pathology. It is interesting to note that ADNP and its related protein ADNP2, proteins that are important for cellular viability (Kushnir et al. 2008) are both expressed in the human hippocampus (Bassan et al. 1999; Dresner et al. 2010; Zamostiano et al. 2001) that is associated with short-term memory and Alzheimer's disease pathology. Importantly, our most recent studies show that ADNP/ADNP2 expression is deregulated in the hippocampus of schizophrenia patients (Dresner et al. 2010). Furthermore, intranasal NAP treatment protects against learning and memory impairments in a mouse model associated with cytoskeletal dysfunctions that are related to schizophrenia (Merenlender-Wagner et al. 2010).

The above studies have been translated into human clinical trials (Allon Therapeutic Inc.) demonstrating that NAP (generic name, davunetide; Gozes et al. 2009) improves cognitive scores in a patient population suffering from amnestic mild cognitive impairment (Markesbery et 
al. 2006; Petersen et al. 2006) that has been associated with tauopathy (Schmechel et al. 2008; Gozes et al. 2009); NAP (davunetide) also improved functional capacity in schizophrenia patients (Javitt 2010) and is being developed for treatment of the tauopathy, progressive supranuclear palsy.

Turning back to VIP, the VIP-related peptide, PACAP (Arimura 1992) also regulates ADNP (Nakamachi et al. 2006; Nakamachi et al. 2008; Zusev and Gozes 2004). At least three receptors for PACAP and VIP have been identified. The PACAP-specific receptor, PAC1 receptor, exhibits a higher affinity for PACAP than VIP, whereas VIP receptors, VPAC1 and VPAC2, have similar affinities for PACAP and VIP (Harmar et al. 1998). VPAC2 has been associated with VIP regulated ADNP expression in astrocytes (Zusev and Gozes 2004). While alternative splice variants of the PAC1 receptor have been associated with VIP neuroprotective activity (Pilzer and Gozes 2006). Interestingly, a peptide mixture including NAP and the related peptide SALLRSIPA induced increases in VIP mRNA, suggesting potential feedback regulation (Spong et al. 2002).

VIP and PACAP show tight association with the regulation of cognitive and emotional functions as detailed in the current issue of the Journal of Molecular Neuroscience.

For example, MacDonald and colleagues review here the involvement of the PACAP/VIP system in synaptic transmission in the hippocampus focusing on PACAP/VIP signaling through different pathways to regulate NMDA receptors in CA1 pyramidal cells. They review the activation of VPAC1 and VPAC2 that increases evoked NMDA currents via the cAMP/ PKA pathway. They further review the activation of the PAC1 receptor that stimulates a PLC/PKC/Pyk2/Src signaling pathway to enhance NMDA receptor function in hippocampal neurons. Importantly, they show that different concentrations of PACAP induce different effects on the both AMPA-evoked current and basal synaptic transmission by activating different receptors. The effects of the VIP-PACAP signaling pathways in learning and memory are also reviewed in using transgenic mice and pharmacological methods.

Regarding emotional behavior, Hammack et al. (corresponding author, May) review the roles for PACAP expression and signaling in the bed nucleus of the stria terminalis (BNST) and the central nucleus of the amygdala as critical structures mediating fear- and anxiety-like behavior. These brain areas organize coordinated fear- and anxiety-like behavioral responses as well as peripheral stress responding to threats via projections to the paraventricular nucleus of the hypothalamus and brainstem regions. They show that BNST PACAP as well as PAC1 are up-regulated following chronic stress and suggest an interaction with the corticotropin-releasing hormone to mediate stress-associated behaviors, including anorexia and anxiety. These studies provide important therapeutic strategies for stress- and anxiety-management.
As highlighted by Lubics and colleagues, in vertebrates, PACAP has been shown to be involved in associative learning but it is not known if it plays a similar role in invertebrates. In an original study, they have now investigated the expression and biochemical roles of PACAP and receptors in the central nervous system of the pond snail Lymnaea stagnalis, one of the best established invertebrate model systems to study the molecular mechanisms of learning and memory. Using MALDI-TOF and immunohistochemistry, they established the presence of the 27 amino acid, PACAP-27 peptide in the cerebral ganglia and the lip region of Lymnaea and a 38 amino acid homologue, squid PACAP-38. They also showed that PACAP and VIP specifically stimulated the synthesis of cAMP in Lymnaea cerebral ganglion homogenates.

As cAMP and related pathways are closely associated with memory formation and storage (Kandel and Schwartz 1982) and as neuroprotection is essential for brain function, VIP and PACAP are placed at center stage with regards to the essence of learning and memory.

The current editorial is just touching the tip of the iceberg, citing only part of my own publications related to learning and memory, while not discussing others (e.g. Goldberg et al. 2009; Visochek et al. 2005). Obviously, there are many more publications in the field and much required future research aiming to uncover the intricate molecular basis of cognitive and emotional behavior. This selective review on VIPPACAP-ADNP-NAP that highlights the current issue of the Journal of Molecular Neuroscience paves the path to new and original research. Our additional comprehensive reviews are accessible for perspective reading (Gozes 2007, 2008; Gozes 2010; Gozes and Brenneman 1989; Gozes et al. 2005; Gozes et al. 2009). New and exciting findings will be presented at the forthcoming VIP-PACAP and related peptides meeting in Eilat, Israel, 2011.

Disclosure I. Gozes serves as the Chief Scientific Officer, Allon Therapeutics Inc., Vancouver, BC, Canada.

\section{References}

Arimura A (1992) Pituitary adenylate cyclase activating polypeptide (PACAP): discovery and current status of research. Regul Pept 37:287-303

Bassan M, Zamostiano R, Davidson A, Pinhasov A, Giladi E, Perl O, Bassan H, Blat C, Gibney G, Glazner G, Brenneman DE, Gozes I (1999) Complete sequence of a novel protein containing a femtomolar-activity-dependent neuroprotective peptide. J Neurochem 72:1283-1293

Dresner E, Agam G, Gozes I (2010) Activity-dependent neuroprotective protein (ADNP) expression level is correlated with the expression of the sister protein ADNP2: deregulation in schizophrenia. Eur Neuropsychopharmacol. doi:10.1016/j.euroneuro.2010.06.004

Glowa JR, Panlilio LV, Brenneman DE, Gozes I, Fridkin M, Hill JM (1992) Learning impairment following intracerebral administration of the HIV envelope protein gp120 or a VIP antagonist. Brain Res 570:49-53 
Goldberg S, Visochek L, Giladi E, Gozes I, Cohen-Armon M (2009) PolyADP-ribosylation is required for long-term memory formation in mammals. J Neurochem 111:72-79

Gozes I (2007) Activity-dependent neuroprotective protein: from gene to drug candidate. Pharmacol Ther 114:146-154

Gozes I (2008) VIP, from gene to behavior and back: summarizing my 25 years of research. J Mol Neurosci 36:115-124

Gozes I (2010) Tau pathology and future therapeutics. Curr Alzheimer Res. (In press)

Gozes I, Brenneman DE (1989) VIP: molecular biology and neurobiological function. Mol Neurobiol 3:201-236

Gozes I, Meltzer E, Rubinrout S, Brenneman DE, Fridkin M (1989) Vasoactive intestinal peptide potentiates sexual behavior: inhibition by novel antagonist. Endocrinology 125:2945-2949

Gozes I, McCune SK, Jacobson L, Warren D, Moody TW, Fridkin M, Brenneman DE (1991) An antagonist to vasoactive intestinal peptide affects cellular functions in the central nervous system. $\mathrm{J}$ Pharmacol Exp Ther 257:959-966

Gozes I, Glowa J, Brenneman DE, McCune SK, Lee E, Westphal H (1993) Learning and sexual deficiencies in transgenic mice carrying a chimeric vasoactive intestinal peptide gene. J Mol Neurosci 4:185-193

Gozes I, Lilling G, Glazer R, Ticher A, Ashkenazi IE, Davidson A, Rubinraut S, Fridkin M, Brenneman DE (1995) Superactive lipophilic peptides discriminate multiple vasoactive intestinal peptide receptors. J Pharmacol Exp Ther 273:161-167

Gozes I, Bardea A, Reshef A, Zamostiano R, Zhukovsky S, Rubinraut S, Fridkin M, Brenneman DE (1996) Neuroprotective strategy for Alzheimer disease: intranasal administration of a fatty neuropeptide. Proc Natl Acad Sci USA 93:427-432

Gozes I, Perl O, Giladi E, Davidson A, Ashur-Fabian O, Rubinraut S, Fridkin M (1999) Mapping the active site in vasoactive intestinal peptide to a core of four amino acids: neuroprotective drug design. Proc Natl Acad Sci USA 96:4143-4148

Gozes I, Morimoto BH, Tiong J, Fox A, Sutherland K, Dangoor D, Holser-Cochav M, Vered K, Newton P, Aisen PS, Matsuoka Y, van Dyck CH, Thal L (2005) NAP: research and development of a peptide derived from activity-dependent neuroprotective protein (ADNP). CNS Drug Rev 11:353-368

Gozes I, Stewart A, Morimoto B, Fox A, Sutherland K, Schmeche D (2009) Addressing Alzheimer's disease tangles: from NAP to AL-108. Curr Alzheimer Res 6:455-460

Harmar AJ, Arimura A, Gozes I, Journot L, Laburthe M, Pisegna JR, Rawlings SR, Robberecht P, Said SI, Sreedharan SP, Wank SA, Waschek JA (1998) International union of pharmacology. XVIII. Nomenclature of receptors for vasoactive intestinal peptide and pituitary adenylate cyclase-activating polypeptide. Pharmacol Rev 50:265-270

Javitt DC (2010) Effects of intranasal AL-108 (davunetide) on neurocognition and functional outcome in schizopherenia. Schizophr Res 117:118-119

Kandel ER, Schwartz JH (1982) Molecular biology of learning: modulation of transmitter release. Science 218:433-443

Kushnir M, Dresner E, Mandel S, Gozes I (2008) Silencing of the ADNP-family member, ADNP2, results in changes in cellular viability under oxidative stress. J Neurochem 105:537-545

Mandel S, Rechavi G, Gozes I (2007) Activity-dependent neuroprotective protein (ADNP) differentially interacts with chromatin to regulate genes essential for embryogenesis. Dev Biol 303:814-824

Markesbery WR, Schmitt FA, Kryscio RJ, Davis DG, Smith CD, Wekstein DR (2006) Neuropathologic substrate of mild cognitive impairment. Arch Neurol 63:38-46

Matsuoka Y, Gray AJ, Hirata-Fukae C, Minami SS, Waterhouse EG, Mattson MP, LaFerla FM, Gozes I, Aisen PS (2007) Intranasal NAP administration reduces accumulation of amyloid peptide and tau hyperphosphorylation in a transgenic mouse model of Alzheimer's disease at early pathological stage. J Mol Neurosci 31:165-170

Matsuoka Y, Jouroukhin Y, Gray AJ, Ma L, Hirata-Fukae C, Li HF, Feng L, Lecanu L, Walker BR, Planel E, Arancio O, Gozes I, Aisen PS (2008) A neuronal microtubule-interacting agent, NAPVSIPQ, reduces tau pathology and enhances cognitive function in a mouse model of Alzheimer's disease. J Pharmacol Exp Ther 325:146-153

Merenlender-Wagner A, Pikman R, Giladi E, Andrieux A, Gozes I (2010) NAP (davunetide) enhances cognitive behavior in the STOP heterozygous mouse-a microtubule-deficient model of schizophrenia. Peptides 31:1368-1373

Nakamachi T, Li M, Shioda S, Arimura A (2006) Signaling involved in pituitary adenylate cyclase-activating polypeptide-stimulated ADNP expression. Peptides 27:1859-1864

Nakamachi T, Ohtaki H, Yofu S, Dohi K, Watanabe J, Hayashi D, Matsuno R, Nonaka N, Itabashi K, Shioda S (2008) Pituitary adenylate cyclase-activating polypeptide (PACAP) type 1 receptor (PAC1R) co-localizes with activity-dependent neuroprotective protein (ADNP) in the mouse brains. Regul Pept 145:88-95

Petersen RC, Parisi JE, Dickson DW, Johnson KA, Knopman DS, Boeve BF, Jicha GA, Ivnik RJ, Smith GE, Tangalos EG, Braak H, Kokmen E (2006) Neuropathologic features of amnestic mild cognitive impairment. Arch Neurol 63:665-672

Pilzer I, Gozes I (2006) VIP provides cellular protection through a specific splice variant of the PACAP receptor: a new neuroprotection target. Peptides 27:2867-2876

Pinhasov A, Mandel S, Torchinsky A, Giladi E, Pittel Z, Goldsweig AM, Servoss SJ, Brenneman DE, Gozes I (2003) Activitydependent neuroprotective protein: a novel gene essential for brain formation. Brain Res Dev Brain Res 144:83-90

Said SI, Mutt V (1972) Isolation from porcine-intestinal wall of a vasoactive octacosapeptide related to secretin and to glucagon. Eur J Biochem 28:199-204

Schmechel DE, Gerard G, Vatakis NG, Harper L, Ross JS, Bari M, Walling D, Stedman M, Winston JL, Morimoto B, Keith JR (2008) A phase 2, double-blind, placebo-controlled study to evaluate the safety, tolerability, and effect on cognitive function of AL-108 after 12 weeks of intranasal administration in subjects with mild cognitive impairment. Alzheimer's \& Dementia: J. Alzheimer's Assoc 4(4):2483

Shiryaev N, Jouroukhin Y, Giladi E, Polyzoidou E, Grigoriadis NC, Rosenmann H, Gozes I (2009) NAP protects memory, increases soluble tau and reduces tau hyperphosphorylation in a tauopathy model. Neurobiol Dis 34:381-388

Spong CY, Auth J, Vink J, Goodwin K, Abebe DT, Hill JM, Brenneman DE (2002) Vasoactive intestinal peptide mRNA and immunoreactivity are decreased in fetal alcohol syndrome model. Regul Pept 108:143-147

Visochek L, Steingart RA, Vulih-Shultzman I, Klein R, Priel E, Gozes I, Cohen-Armon M (2005) PolyADP-ribosylation is involved in neurotrophic activity. J Neurosci 25:7420-7428

Vulih-Shultzman I, Pinhasov A, Mandel S, Grigoriadis N, Touloumi O, Pittel Z, Gozes I (2007) Activity-dependent neuroprotective protein snippet NAP reduces tau hyperphosphorylation and enhances learning in a novel transgenic mouse model. J Pharmacol Exp Ther 323:438-449

Zamostiano R, Pinhasov A, Gelber E, Steingart RA, Seroussi E, Giladi E, Bassan M, Wollman Y, Eyre HJ, Mulley JC, Brenneman DE, Gozes I (2001) Cloning and characterization of the human activity-dependent neuroprotective protein. J Biol Chem 276:708-714

Zusev M, Gozes I (2004) Differential regulation of activity-dependent neuroprotective protein in rat astrocytes by VIP and PACAP. Regul Pept 123:33-41 